\title{
Matriz de Competitividade e o papel dos mercados emergentes nas exportações argentinas e brasileiras *
}

\author{
Virginia Laura Fernández ****** \\ Marcelo Luiz Curado ${ }^{* * * * * * * * * * *}$
}

\begin{abstract}
Resumo
O objetivo deste trabalho é analisar a evolução da estrutura de exportações da Argentina e do Brasil entre 1985 e 2010 a partir da matriz de competitividade desenvolvida originalmente por Fajnzylber e Mandeng. Especificamente, pretende-se analisar a relação existente entre o formato da matriz de competitividade e a evolução dos mercados de destino das exportações brasileiras e argentinas analisados (OCDE, Mercosul, Ásia em Desenvolvimento e MUNDO). Os resultados confirmam que os mercados dos países emergentes favorecem as exportações mais dinâmicas e competitivas da Argentina e do Brasil. Entretanto, enquanto as exportações argentinas e brasileiras ao Mercosul estão compostas por manufaturas mais sofisticadas, as exportações aos países em desenvolvimento da Ásia são quase em sua totalidade de recursos naturais e commodities.
\end{abstract}

Palavras-chave: Padrão de Exportações da Argentina e do Brasil, Matriz de Competitividade de FajnzylberMandeng, Recursos Naturais.

\section{Abstract \\ The competitiveness matrix and the role of emerging markets in Argentine and Brazilian exports}

The general objective of this study is to analyze the evolution of Argentina and Brazil's export structures between 1985 and 2010, through the competitiveness matrix developed by Fajnzylber and Mandeng. The specific objective is to identify links between the form that the competitiveness matrix takes over time and the evolution of the markets analyzed (OECD, Mercosur, Asia Developing and WORLD). The results confirm that the markets of emerging countries favor the most dynamic and competitive exports from Argentina and Brazil. However, while the Argentine and Brazilian exports to Mercosur are composed of more sophisticated manufactures, exports to developing countries in Asia are almost entirely natural resources and commodities.

Keywords: Argentine and Brazilian Export Patterns; Fajnzylber Mandeng Competitiveness Matrix; Natural Resources.

JEL F10, O54, Q18.

\section{Introdução}

Historicamente as economias latino-americanas caracterizaram-se por possuírem estruturas produtivas muito heterogêneas em que coexistiam setores de alta tecnologia e

* Artigo recebido em 15 de abril de 2016 e aprovado em 6 de novembro de 2018.

** Professora da Facultad de Ciencia Política y Relaciones Internacionales da Universidad Nacional de Rosario, Argentina.

*** Professora do Departamento de Economia e do Mestrado Profissional em Desenvolvimento Econômico da Universidade Federal do Paraná (UFPR), Curitiba, PR, Brasil. E-mail: virginialaurafernandez@yahoo.com.ar.

${ }^{* * * *}$ Professor Titular do Departamento de Economia e do Programa de Pós-Graduação em Desenvolvimento Econômico da Universidade Federal do Paraná (UFPR), Curitiba, PR, Brasil.

${ }^{* * * * * *}$ Bolsista de Produtividade em Pesquisa do Conselho Nacional de Desenvolvimento Científico e Tecnológico (CNPq), Brasília DF, Brasil. E-mail: mlcurado@gmail.com. 
produtividade com setores de baixíssima produtividade. A escassa diversificação produtiva está no coração da dependência externa da região, especialmente na configuração de uma balança comercial fortemente dependente das exportações de produtos primários e commodities. Para autores como Raúl Prebisch, Celso Furtado e Fernando Fajnzylber, tais caraterísticas limitaram o potencial de crescimento e desenvolvimento da região e tornaram os resultados comerciais altamente instáveis, tendo em vista que a exportação de produtos primários e a determinação dos preços das commodities locais não eram definidos pelas próprias economias, mas pela dinâmica do mercado internacional.

O processo de industrialização e a diversificação da pauta de exportação, especialmente entre 1950-1980, reduziram relativamente mas não resolveram o problema da dependência externa. Os desequilíbrios comerciais e a vulnerabilidade externa permaneceram como fenômenos recorrentes, justificando sua presença na análise econômica cepalina. Bielschowsky (1998, p. 31), por exemplo, sustenta que: "Com variações adaptativas aos diversos contextos de comércio internacional e às variadas condições de financiamento internacional, o argumento da vulnerabilidade externa acompanha as cinco décadas de reflexão cepalina".

Os processos de abertura comercial e a estabilização econômica não promoveram a superação do problema da vulnerabilidade externa dos países da região; em alguns casos estes problemas foram agravados. No caso brasileiro a combinação de abertura comercial e valorização cambial associada à estabilização promovida pelo Plano Real a partir de julho de 1994 foram, em grande medida, responsáveis pela eclosão de uma grave crise cambial em janeiro de 1999 (Belluzzo, 1999).

As mudanças ocorridas no comércio internacional a partir dos primeiros anos do século XXI, especialmente a entrada da China e o processo de reprimarização da pauta exportadora da América Latina deram novo fôlego às investigações na área em nível internacional ${ }^{1}$. É neste contexto que está inserido este trabalho. $\mathrm{O}$ artigo analisa as particularidades do padrão de exportações e de competitividade internacional da Argentina e do Brasil na nova ordem mundial, caraterizada pelas mudanças radicais nos padrões mundiais de produção, consumo e intercâmbio comercial. A análise é realizada a partir de um corpo teórico latino-americano que contribui na interpretação das especificidades dos processos de crescimento e desenvolvimento da região.

O objetivo mais específico do trabalho é analisar o padrão de exportações da Argentina e do Brasil, aplicando a matriz de competitividade originalmente elaborada por Fajnzylber e Mandeng para o período 1985-2010. Pretende-se analisar a relação existente entre o formato da matriz de competitividade e a evolução dos mercados de destino das exportações brasileiras e argentinas analisados (OCDE, Mercosul, Ásia em Desenvolvimento e MUNDO), tendo como

(1) Só para citar um exemplo da importância deste debate, em 2015 a Latin American Perspectives , v. 42, n. 6 (205), dedicou um número exclusivo à discussão sobre os impactos da China para a América Latina, com foco nas relações comerciais e na discussão sobre os impactos da reprimarização da pauta exportadora latino-americana. 
lente de análise a relevância, para a competividade, dos recursos naturais e das manufaturas não baseadas em recursos naturais. Finalmente, discute-se a utilidade do uso desta matriz para identificar as mudanças estruturais que ocorreram nos padrões de consumo, produção e comércio internacional no começo do século XXI.

Os resultados obtidos confirmam que os mercados dos países emergentes favorecem as exportações mais dinâmicas e competitivas da Argentina e do Brasil. Entretanto, enquanto as exportações argentinas e brasileiras ao Mercosul estão compostas por manufaturas mais sofisticadas, as exportações para os países em desenvolvimento da Ásia são quase em sua totalidade de recursos naturais e commodities.

Importa sublinhar, neste ponto, que o pensamento econômico brasileiro convencional vem relativizando, quando não menosprezando, a relevância política e econômica do Mercosul, sob argumento de que os custos e restrições para o livre comércio prejudicaram o Brasil. Os resultados deste estudo sugerem uma interpretação distinta. Como se verá, o mercado para o qual o Brasil mantém a melhor matriz de competitividade (grande presença de exportações em Situação Ótima e em grupos dinâmicos em geral) durante todos os subperíodos analisados é o Mercosul, sobretudo se diferenciarmos em termos de qualidade. É apenas para este mercado que os produtos com alto valor agregado crescem em volume e participação dentro das exportações brasileiras. Isso não ocorreu com as exportações à OCDE e muito menos para os países em desenvolvimento da Ásia.

A metodologia de análise combina os elementos conceituais da matriz de competitividade de Fajnzylber e Mandeng e do Competitiviness Analysis of Nations (CAN) desenvolvidos em 1991 por Fajnzylber em "Inserción internacional e innovación institucional" e Mandeng em "Competitividad internacional y especialización“, na Revista da Cepal. A fonte de informação é a base de dados TradeCAN da Cepal, que conglomera mais de $90 \%$ do comércio internacional e agrupa informação de 73 países $^{2}$.

O artigo está organizado da seguinte forma. Após esta breve introdução, a seção 1 apresenta uma caraterização do contexto internacional do início do século XXI, destacando os desafios que a presença da China traz às economias latino-americanas. A seção 2 faz uma apresentação dos principais conceitos da matriz de competitividade de Fajnzylber e Mandeng e inserção na discussão teórica estruturalista sobre a dependência dos recursos naturais. A seção 3 apresenta uma atualização da matriz de competitividade argentina e brasileira para os períodos 1985-1990, 1990-2000, 2000-2007 e 2007-2010. Na seção 4 são realizadas algumas reflexões sobre o uso da matriz de competitividade de Fajnzylber e Mandeng para analisar os resultados obtidos no trabalho. A seguir são apresentadas as considerações finais do trabalho.

(2) É importante mencionar que apesar da base de dados ter surgido dos trabalhos conjuntos dos autores mencionados, não tem sido muito utilizada com a finalidade de analisar a competitividade dos países, nos últimos anos. Por esta razão, a proposta de utilizar dita metodologia implica um esforço adicional de pesquisa, operacionalização e verificação do sistema. Por isso, ainda que se tenha utilizado o TradeCAN, em alguns casos foram efetuados cálculos manuais que coincidiram pontualmente com os derivados do software 
Virginia Laura Fernández, Marcelo Luiz Curado

\section{0 contexto internacional do início do século XXI: globalização e ascensão da China}

As transformações produtivas, de consumo e no comércio internacional que marcaram a transição para o século XXI, estão ligadas aos resultados da globalização, que começou nas últimas três décadas do século XX, onde a tecnologia mudou as dimensões de tempo e espaço. Paralelamente a esse processo, a entrada da China ao comércio internacional e as novas formas produtivas que adquiriram as cadeias globais de valor, reconfiguram a divisão internacional do trabalho e trazem de volta para o centro do debate a controvérsia dos recursos naturais para o desenvolvimento das economias latino-americanas. (Altamonte; Sánchez, 2016; Bekerman et al., 2014; Bittencourt, 2012).

A literatura sobre comércio internacional estabelece que a organização econômica, as inovações nas áreas de tecnologia da informação e comunicação (TIC) e no transporte, foram essenciais para estabelecer um novo paradigma industrial e comercial global. A intensificação da fragmentação internacional da produção, a dispersão de processos produtivos e a montagem de componentes dentro dos processos de produção integrados verticalmente em vários países (Hermida et al., 2016, p. 2) são fenômenos que se destacam neste período e que condicionam notavelmente os fluxos de comércio internacional. Hiratuka (2015, p. 16), analisando o caso brasileiro, destaca quais as grandes mudanças na estrutura de produção global que condicionaram a inclusão dos países em desenvolvimento no comercio e produção mundial: a intensa desverticalização com fragmentação de atividades, e uma grande transferência internacional de etapas produtivas. Isso levou a que a produção mundial adquirisse uma forma de rede internacional na qual diferentes países e empresas se integraram nas etapas da cadeia de valor, sob a coordenação das grandes empresas. Como resultado, segundo o autor, intensificou-se o deslocamento das atividades industriais aos países em desenvolvimento e emergiu a Ásia em desenvolvimento, especialmente a China, como líder mundial na produção e exportação de manufaturas. No entanto, a principal contrapartida deste processo seria a tendência de concentração e centralização da capacidade de comando das cadeias globais de valor nas grandes corporações globais que dominam os ativos tecnológicos das mesmas. A evidência empírica de Hermida et al., que analisa uma amostra de 40 países entre 2003-2011, sustenta a hipótese de que a fragmentação e a participação em cadeias globais de valor garantem taxas de crescimento mais elevadas, mas distingue que a posição dos países dentro das cadeias torna-se muito importante. Assim, os países especializados nas etapas da cadeia em setores de alta tecnologia e serviços tendem a crescer mais rapidamente do que os países localizados nas etapas de setores primários (2016, p. 1); o que no caso da América Latina, implicaria que a controvérsia da inserção externa com base nos recursos naturais é mantida.

Por sua vez, Hiratuka e Sarti (2017, p. 197-198) enumeram quatro tendências globais que caracterizam a nova realidade mundial. A primeira é a reorganização das estratégias globais de atividades produtivas das empresas transnacionais (ETN) e seu impacto no desenvolvimento industrial. A segunda, a emergência da China como o principal fornecedor global de produtos manufaturados. A terceira, a continuidade da concentração do conhecimento tecnológico nas grandes ETNs. Finalmente, e em resposta à crise de 2008-2009, o lançamento recente de 
políticas nacionais ativas para recuperar atividades industriais e promover a inovação em novas áreas e setores. Esse retorno às políticas de revitalização das atividades produtivas e de incentivos à inovação e o maior protecionismo à indústria nacional, tanto nos EUA quanto na União Europeia e até na China, já havia sido apresentado por Hiratuka (2015, p. 318-319).

Vale destacar que os impactos dessa crise se explicitam na redução das taxas de crescimento das exportações globais e de manufaturados, que passaram de crescer entre 20032007 a uma taxa média anual de 16,6\% e 14,8\% respectivamente, para crescer entre 2009-2013 em apenas $3,1 \%$ e $2,6 \%$. Hiratuka $(2015$, p. 311$)$. A disputa por este mercado em declínio se aprofundou nos últimos anos e é neste período que a economia asiática aparece como o concorrente aguerrido em terceiros mercados.

Analisando especificamente o efeito da China para as economias argentina e brasileira e, em geral, para o caso da América Latina, a literatura ressalta pelo menos três fatores positivos e dois negativos. Entre os positivos destaca-se a dinamização da demanda de commodities e recursos naturais, como resultado de taxas de crescimento extremamente altas na China ${ }^{3}$ e em outras economias asiáticas emergentes. Isso levou ao aumento do volume negociado, ao aumento dos preços das commodities agrícolas, minerais e metais e à redução da vulnerabilidade externa da Argentina e do Brasil pelos superávits comerciais ${ }^{4}$ durante as primeiras décadas do século XXI (Baltar; Prates, 2014, p. 5; Dussel Peters, 2012, p. 53). Por outro lado, o dinamismo das economias emergentes, particularmente as da América Latina, gerou uma crescente demanda por bens manufaturados, o que no caso da Argentina e do Brasil derivou num padrão de exportações mais sofisticado para os mercados da América do Sul. O terceiro elemento positivo é a melhora dos salários reais dos trabalhadores pelo barateamento dos produtos manufaturados chineses. Curado (2015, p. 89), apoiado em Castro (2008, p. 4), destaca que a redução do custo da produção industrial que surge com a emergência da China deriva na massificação internacional do consumo, incorporando bens industriais na cesta de consumo dos trabalhadores nos países desenvolvidos e também nos países de baixa renda.

Dentro dos efeitos negativos, o primeiro é a reprimarização do padrão de exportações dos países latino-americanos. Os recursos naturais - considerados a principal vantagem comparativa que dominou a inserção internacional da região no início do século $\mathrm{XX}$ reaparecem como a armadilha à nova inserção no mundo.

Assim, a região após os esforços de industrialização e diversificação do padrão de exportação entre 1950 e 1980 que permitiram uma melhora da estrutura produtiva, dedicou os anos 80 para resolver os problemas financeiros da dívida externa e inflação; abriu espaço durante os anos 90 para implementar políticas de abertura indiscriminada das economias e a

(3) Segundo dados do Banco Mundial apresentados em Bekerman et al. (2014, p. 58), a economia chinesa cresceu entre 1980 e 2010 a uma taxa anual média de 10\%, com um significativo incremento do PIB per capita de 205 a 4.280 dólares em 2010; permitindo que 500 milhões de pessoas saíssem da pobreza e se tornando o principal país manufatureiro e exportador do mundo.

(4) O balanço comercial de bens e serviços (em dólares a preços correntes) da Argentina foi superavitário durante o período 2001-2012 e do Brasil durante 2002-2007, segundo dados do Banco Mundial. 
Virginia Laura Fernández, Marcelo Luiz Curado

liberalização dos mercados seguindo o Consenso de Washington; e, finalmente, chega ao século XXI com a mesma controvérsia de aprofundar a primarização de sua economia diante a China. O gigante asiático estaria incentivando a exportação de matérias-primas com um mínimo de valor agregado pelos países da região. A China resgatou o debate sobre os processos de industrialização, os custos e benefícios da especialização agrícola e agroindustrial e a "sustentabilidad en el largo plazo de estos procesos productivos y comerciales en América Latina, particularmente de Argentina, Brasil y Chile" (Dussel Peter, 2012, p. 54-55); (Kats; Dussel Peter, 2002). O risco de uma nova dependência e vulnerabilidade externa está presente e atrelado a "(...) una especialización primarizada, complementaria con la creciente demanda china que llevaría a una situación similar a la de la década de 1930. Esto generaría una posible desestructuración del sistema productivo de las economías de la región, afectadas por la presión competitiva de las exportaciones chinas" (Bekerman, 2014, p. 57).

O segundo efeito negativo é que a concorrência da China nos produtos manufaturados cada vez mais sofisticados tanto nos mercados domésticos como em terceiros mercados se tornou mais intensa após a crise internacional de 2008-2009, como foi dito. Esse segundo efeito reforça o primeiro - a reprimarização das economias da região. (Cunha et al, 2012, p. 210-211) enfatizam que a China intensificou sua presença na periferia capitalista, no contexto da crise global, como uma estratégia para compensar a perda de dinamismo nas regiões centrais. No caso da Argentina e do Brasil, o impacto da acirrada concorrência chinesa é esperado principalmente nas exportações mais sofisticadas destinadas à América do Sul. Já existem vários estudos sobre a perda de competitividade dos produtos manufaturados argentinos e brasileiros em terceiros mercados, especialmente em relação aos países asiáticos, entre outros Bekerman et al. (2014), Hiratuka et. al. (2012), Carneiro (2012), Costa et al. (2016), Módolo e Hiratuka (2014) e Mancini (2014). A maior parte das pesquisas destaca que o forte vínculo comercial mais sofisticado entre Argentina e Brasil é sustentado pela indústria automotiva, onde a China não pôde acessar por ser um comércio administrado pelo Mercosul.

Bekerman et al. (2014, p. 73) revela que a Argentina, entre 1998-2011, perdeu participação em mais de 6 pontos percentuais de quota de mercado nas importações brasileiras, enquanto a China aumentou sua participação em mais de 12 pontos percentuais. As indústrias siderúrgica e têxtil são as mais relevantes para explicar a perda no mercado brasileiro. Em seguida estão a indústria petroquímica (borracha e plástico) e a de bens de capital. Contudo, embora o Brasil tenha melhorado sua participação no mercado argentino como um todo, ganhando espaço em relação à União Europeia e os Estados Unidos, sofreu o impacto da concorrência chinesa em setores específicos como os têxteis e hardware informático. (Ibid. 2014, p. 80)

Finalmente analisando o mercado regional da Aladi, entre 2002-2009, a concorrência chinesa teria sido mais intensa e influenciado a perda de quota de mercado da Argentina e do Brasil em três sectores de alta tecnologia: produtos químicos, informática e telecomunicações, e máquinas e equipamentos. As perdas foram mais intensas nas exportações de informática e 
telecomunicações, nas que entre 2005 e 2009 85\% das perdas de mercado da Argentina e do Brasil resultaram da presença da China. (Hiratuka et al., 2012, p. 144)

Com este pano de fundo e com ênfase no impacto que a ascensão da economia chinesa traz para a reconfiguração dos países latino-americanos e da Argentina e do Brasil no comércio internacional é que analisamos a competitividade das exportações de tais países através de uma metodologia desenvolvida na região. Procuramos assim, usar uma ferramenta estruturalista latino-americana que foi pouco manipulada para verificar se ela é apropriada para interpretar alguns fenômenos mais atuais da realidade. Em seguida, descreve-se o surgimento e o objetivo que permeou a criação da Matriz de Competitividade de Fajnzylber e Mandeng

\section{A Matriz de Competitividade de Fajnzylber e Mandeng}

Em 1991, Fernando Fajnzylber e Ousmène Mandeng publicaram artigos na Revista da Cepal analisando a relação entre os padrões de exportação e competitividade. O objetivo básico dos autores era construir uma ferramenta para o desenho de estratégias e políticas comerciais nacionais e setoriais para as economias da AL. O objetivo imediato era analisar a estrutura das exportações de vários países, principalmente latino-americanos, e seu nível de competitividade para o decênio de 1979/1988.

Com a finalidade de interpretar a base de dados do comércio mundial, a Oficina de Estatística das Nações Unidas desenvolveu um sistema de análise que doravante denominamos "metodologia Fajnzylber-Mandeng". Esta metodologia trabalha os conceitos de posicionamento e eficiência, os quais resultam em uma classificação quaternária - designada matriz da competitividade - que permite verificar a competitividade setorial de um país em relação à expansão da demanda ${ }^{5}$. Esta metodologia será utilizada para analisar a estrutura de exportações da Argentina e do Brasil, entre 1985 e 2010. Antes, no entanto, será realizada uma breve apresentação das conclusões que Fajnzylber alcançou no começo dos anos 90 sobre as exportações das economias latino-americanas (e de outros países em desenvolvimento) e seu nível de competitividade, que servirão de parâmetro para nossa análise.

Fajnzylber (1991) destaca quatro pontos de relevância para nossa pesquisa. O primeiro é que os países ganhadores têm um padrão de exportações menos baseado em recursos naturais que os perdedores ${ }^{6}$. O segundo ponto é que existem países membros da OCDE que mantêm uma inserção externa superavitária em atividades ligadas aos recursos naturais, e deficitária no setor manufatureiro, como Canadá, EUA, Noruega, Dinamarca e Reino Unido, nos quais o progresso técnico da indústria manufatureira está inexoravelmente aliado aos recursos naturais.

(5) Esta forma de analisar o padrão de inserção internacional dos países resultou, inclusive, em um software desenvolvido pela Cepal: o TradeCAN

(6) Embora atualmente sejam 34 países integrantes da OCDE, este trabalho, para manter certa coerência analítica e possibilitar uma comparação mais fiel, considera apenas 24 países, que integravam à OCDE à época da análise de Fajnzylber e Mandeng. Quais sejam: Alemanha, Austrália, Áustria, Bélgica, Canadá, Dinamarca, Espanha, Estados Unidos, Finlândia, França, Grécia, Irlanda, Islândia, Israel, Itália, Japão, Luxemburgo, Noruega, Nova Zelândia, Holanda, Portugal, Reino Unido, Suécia, Suíça. Quando este trabalho fale em OCDE são esses os países considerados. 
Virginia Laura Fernández, Marcelo Luiz Curado

Um terceiro elemento de análise é que a América Latina não é o principal fornecedor de recursos naturais da OCDE e do mundo. Em 1989 a região participava apenas com 10\% das importações de recursos naturais e $5 \%$ das manufaturas baseadas em recursos naturais (Fajnzylber, 1991, p. 171). Finalmente, o autor menciona que no período analisado as importações de manufaturas baseadas em recursos naturais da OCDE reduziram sua participação, passando de um terço para um quarto do total. Isto "refleja y confirma la tendencia a la reducción del uso de recursos naturales y particularmente de energía en la actividad económica de los países desarrollados" (Fajnzylber, 1991, p. 169). Este ponto, numa concepção de competitividade condicionada pela demanda, preocupou ao autor e instou-o a sugerir estratégias de política econômica para modificar o padrão de exportações das economias da AL.

Estes resultados serão confrontados com os dados para a Argentina e Brasil entre 1985 e 2010. Vale salientar que houve um elemento que não foi considerado pelo autor (nem poderia ter sido, já que Fajnzylber morreu em 1991) e que é muito importante na análise do comportamento do comércio internacional do período: a ascensão da China, Índia e outros países emergentes no mercado produtivo e de consumo mundial, o que reverteria tal tendência ao estancamento da demanda por recursos naturais básicos e manufaturados.

\subsection{Os conceitos e a metodologia: a definição da Matriz de Competitividade}

A metodologia desenvolvida por Fajnzylber-Mandeng para construir a matriz de competitividade de um país analisa simultaneamente os dados das estruturas de exportações dos países e da estrutura de importações da $\mathrm{OCDE}^{7}$. Fajnzylber define o posicionamento como o dinamismo relativo de um grupo específico nas importações da OCDE, qualificando-o como favorável quando a participação deste grupo aumenta e desfavorável quando diminui (1991, p. 151). Mandeng afirma que o posicionamento se refere às variações estruturais causadas pela demanda ou pela oferta, na estrutura total das importações da OCDE (Mandeng, 1991a, p. 26). Portanto, quando se mede o posicionamento analisam-se de maneira dinâmica todos os grupos exportados pelo país com relação aos grupos importados pela OCDE. Desta forma, o posicionamento é favorável quando os grupos exportados se encontram entre os que tiveram um aumento na demanda da OCDE.

A eficiência, por sua vez, é entendida como a participação relativa de um país em um grupo específico, considerando-a alta quando a participação nas importações da OCDE aumenta e baixa quando diminui. (Fajnzylber, 1991, p. 151). De outro ponto de vista, pode-se analisar a eficiência das exportações através da especialização de cada país. Segundo Mandeng, para cada país, a especialização refere-se à relevância de um setor específico em relação a sua posição competitiva global e/ou com relação a uma estrutura de mercado (1991a, p. 26). Em

(7) Para aprofundar no modelo da Matriz de Competitividade ver Mandeng (1991a; 1991b). Em síntese, a participação total de um país $\left(\boldsymbol{S}_{\boldsymbol{j}}\right)$ num momento específico será igual ao produto ponderado da participação de suas importações de determinado grupo setorial $\left(s_{i j}\right)$ e a relevância de dito grupo nas importações do mercado $\left(s_{i}\right): S_{j}=\sum_{i=1}^{n} \frac{M_{i j} M_{i}}{M_{i} M}=\sum_{i=1}^{n} s_{i j} s_{i}$. 
outras palavras, a eficiência mede a participação de um país em um determinado grupo importado pela OCDE. Assim, a eficiência é alta quando aumenta a participação de mercado em um determinado grupo, independentemente se aquele grupo ganhou ou perdeu espaço na demanda da OCDE. Em síntese: está-se mal posicionado quando se exportam grupos de baixo dinamismo relativo, e se é pouco eficiente quando para qualquer grupo nos quais se participe, dita participação diminui com relação aos outros países que exportam ao mercado analisado (Fajnzylber, 1991, p. 151)

Para os autores, e mais especificamente para Fajnzylber (1991), a eficiência global dos países permitiu classificá-los como ganhadores ou perdedores, dependendo se sua participação no mercado da OCDE cresceu ou decresceu. Como exemplo vejam-se os casos da Argentina e do Brasil. No período estudado por Fajnzylber, a Argentina reduziu sua participação no mercado da OCDE de $0,4 \%$ para $0,25 \%$, motivo pelo qual é classificada como "perdedora". Em contrapartida, a variação da participação do Brasil aumentou em 20\%, obtendo em 1988 uma quota de mercado de 1,19\%, sendo, portanto, incluído entre os países "ganhadores" (1991, p. 154,155$)$

Depois de diferenciar os países entre ganhadores e perdedores, Fajnzylber (1991) analisa a composição de suas exportações combinando os conceitos de eficiência e posicionamento. Tal combinação, que permite identificar quatro situações do padrão de exportações, é chamada pelos autores de matriz de competitividade:

a) posicionamento favorável e eficiência alta, denominada situação ótima;

As exportações que estão em situação ótima expressam que um país amplia suas exportações em setores nos quais há crescimento na demanda da OCDE (grupos dinâmicos). Quando um país tem uma grande proporção de suas exportações em situação ótima, significa que é competitivo produtivamente e que está especializado em setores que estão ganhando espaço no mercado da OCDE.

b) posicionamento desfavorável e eficiência alta; denominada situação de vulnerabilidade;

A situação de vulnerabilidade diz respeito aos grupos de exportações no qual o país está se especializando ou sendo mais competitivo, mas estes grupos estão perdendo dinamismo no mercado da OCDE (grupos não dinâmicos). Uma situação de vulnerabilidade poderia indicar perspectivas futuras negativas caso seja mantida a tendência de queda na demanda por estes bens. Para o caso da AL, onde os recursos naturais são preponderantes na definição do padrão de especialização, uma tendência à redução da demanda por estes bens poderia evidenciar a vulnerabilidade de suas exportações.

c) posicionamento favorável e eficiência baixa, denominada oportunidades perdidas;

As oportunidades perdidas dizem respeito aos grupos de exportações em que há crescimento da demanda da OCDE, mas cuja quota de mercado do país analisado está 
Virginia Laura Fernández, Marcelo Luiz Curado

diminuindo com relação a outros competidores. Poder-se-ia dizer que a estrutura de exportações do país nesses grupos não estaria se adaptando às mudanças na estrutura importadora da OCDE. Neste caso também é relevante indagar sobre a duração desta tendência, já que se for conjuntural não é preciso uma mudança na orientação do comércio, mas caso persista, é importante reorientar a política comercial para retornar aos níveis de competitividade já alcançados, ou melhorá-los.

d) posicionamento desfavorável e eficiência baixa, denominada situação de retirada;

As exportações em situação de retirada refletem os grupos nos quais o país está perdendo quota de mercado e, por sua vez, a demanda destes grupos está decrescendo por parte da OCDE. Esta classificação da matriz de competitividade não é sempre negativa, já que poderia estar representando uma situação de adaptabilidade por parte da estrutura de exportações do país às mudanças nas importações da OCDE.

A classificação permite analisar a proximidade ou distanciamento que existe entre a estrutura de exportações dos países e a estrutura de importações da OCDE e detectar quais são os elementos que podem dificultar ou favorecer o padrão de exportações de cada país. Para a Argentina e o Brasil, os dados da matriz de competitividade para o período 1979/1988 são representados no Gráfico 1. Como pode ser visto, o Brasil, como país ganhador, tinha uma porcentagem de exportações em situação ótima muito elevada, e em situação de retirada e de oportunidades perdidas muito baixas. Para Argentina, país perdedor de mercado, a situação era inversa.

Gráfico 1

Matriz de Competitividade 1979/1988 (em \% de exportações)

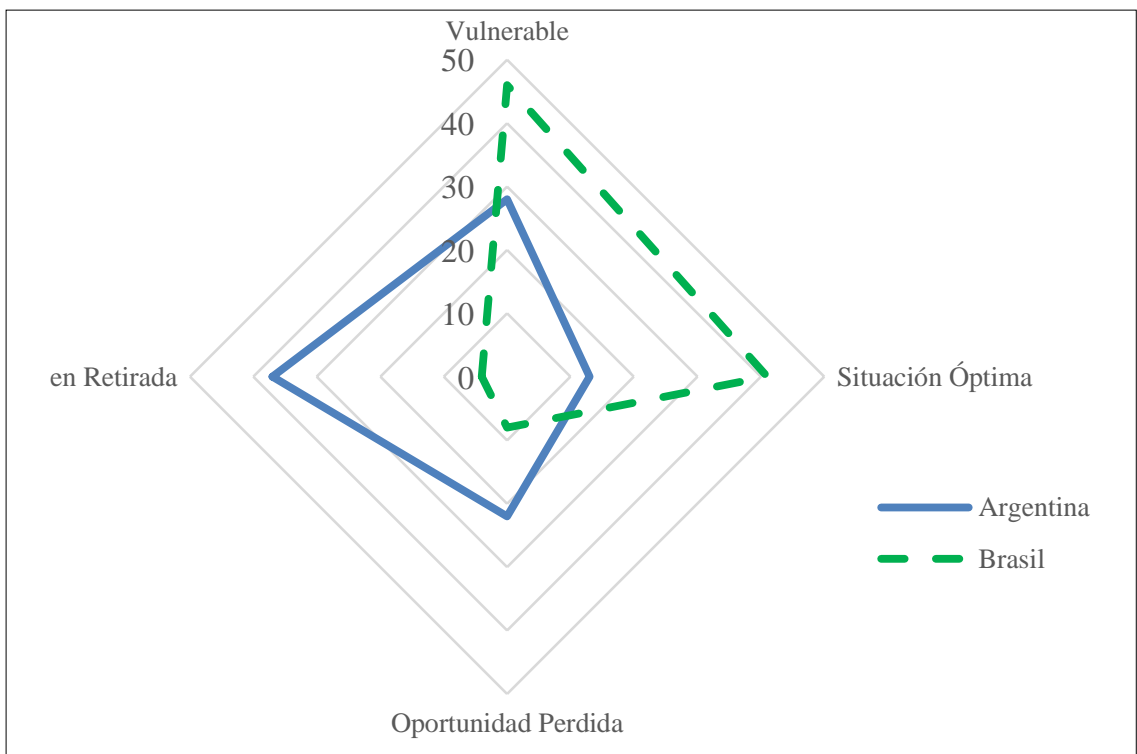

Fonte: Elaboração própria com base em Fajnzylber (1991). 


\section{Matrizes de Competitividade argentina e brasileira atualizadas}

Considerando que a Matriz de Competitividade estabelece relações entre a demanda de um mercado e as exportações de um país, para conhecer a evolução das matrizes argentinas e brasileiras é necessário descrever a evolução da estrutura de cada mercado: mundial (MUNDO), dos países industrializados (OCDE), do Mercado Comum do Sul ${ }^{8}$ (Mercosul), dos países da Ásia em Desenvolvimento ${ }^{9}$ (AD); em paralelo com a estrutura de exportações de cada país ${ }^{10}$.

É importante mencionar que a composição das demandas MUNDO e OCDE se mantêm praticamente idênticas no período analisado. Ademais, em termos de importância nas importações da OCDE no ano de 1985 representavam 83\% das importações mundiais e 25 anos depois ainda alcançavam mais de $64 \%$. Ou seja, a demanda mundial foi e segue sendo fortemente estimulada pela demanda dos países industrializados. Por este motivo Fajnzylber e Mandeng analisaram exclusivamente a demanda da OCDE.

É digno de notar a presença da $\mathrm{AD}$, que também ganhou espaço dentro das importações mundiais, absorvendo parte da redução da OCDE e mais que duplicando sua participação ao longo do período analisado, havendo alcançado, em 2010, 28\% das importações mundiais ${ }^{11}$. Esse avanço da $\mathrm{AD}$ não foi previsto pelos autores antes mencionados.

É singular sobre isto que, embora as estruturas das demandas da OCDE e da AD tenham melhorado desde 1985 em favor das Manufaturas não Baseadas em Recursos Naturais, as estruturas de exportações argentina e brasileira a esses mercados não tenham evoluído neste sentido. Paradoxalmente, a $\mathrm{AD}$, como resultado de sua influência, reforçou a primarização do padrão de exportações da Argentina e do Brasil. Sobre esse aspecto, é importante antecipar que no ano de 1990 a Argentina concentrava 40\% y Brasil 53\% das exportações à AD em manufaturas de alto valor agregado, mas não conseguiram consolidar este patamar nas décadas seguintes ${ }^{12}$.

O oposto aconteceu com as exportações argentinas e brasileiras ao Mercosul. Houve uma clara e expressiva redução da participação dos Recursos Naturais e da Energia na estrutura da demanda do Mercosul. A mesma mudança estrutural ocorreu na matriz de exportações argentinas para este mercado: as Manufaturas não Baseadas em Recursos Naturais ganharam muita relevância. Por sua vez, na matriz de exportações brasileiras, tais manufaturas cresceram continuamente até alcançar quase $87 \%$ do total em 2010. Em outras palavras, a demanda do

(8) Integrado neste artigo pelos seguintes países: Argentina, Brasil, Paraguai e Uruguai.

(9) Integrado neste artigo pelos seguintes países: Arábia Saudi, China, Chipre, Filipinas, Hong Kong, Índia, Indonésia, Jordânia, Macau, Malásia, Mascate Omã, Nepal, Paquistão, Qatar, República da Coréia do Sul, Singapura, Síria, Tailândia, Turquia.

(10) Uma descrição mais detalhada não é possível de ser feita neste artigo, mas em anexo encontram-se dados pertinentes à análise. Ver em Anexo 1 - Tabela Estrutura dos Mercados nas Importações Mundiais

(11) Ver em Anexo 2- Tabela Quota de cada Mercado nas Importações Mundiais.

(12) Ver em Anexo 1 - Tabela Estrutura Comercial da Argentina e do Brasil. 
Virginia Laura Fernández, Marcelo Luiz Curado

Mercosul por produtos de maior valor agregado gerou um impacto direto e positivo sobre as exportações argentinas e brasileiras.

Pode se dizer que a demanda da $\mathrm{AD}$ acentuou a primarização da inserção externa da Argentina e do Brasil. A demanda da OCDE, por sua vez, não vem favorecendo o desenvolvimento industrial da economia argentina e reforça a primarização da economia brasileira. Em contrapartida, o Mercosul tem desempenhado um papel importante na melhora de ambos os padrões comerciais da Argentina e do Brasil.

Neste capítulo, vamos apresentar primeiramente as Matrizes de Competitividade da Argentina e do Brasil para os mercados MUNDO, OCDE, Mercosul e AD, por subperíodo. A descrição do resultado das matrizes ocorre em três etapas, primeiro para o mercado MUNDO e OCDE, depois para o Mercosul e finalmente para AD. Por fim, delineiam-se os principais usos da MC para interpretar as mudanças estruturais das variáveis em estudo.

O período de análise se divide em quatro subperíodos: 1985-1990, 1990-2000, 20002007 e 2007-2010. Os anos entre as extremidades refletem a série completa do TradeCAN. Os subperíodos se relacionam, respectivamente, com a conformação do Mercosul, a década de implantação do Consenso de Washington na América Latina, a grande expansão dos países asiáticos como consumidores e oferentes mundiais, e a crise mundial de 2007-2008.

\subsection{Os resultados}

A Matriz de Competitividade, como vimos, relaciona a evolução do padrão comercial de um país com a evolução de seu mercado. É possível visualizar por meio de radiais, para cada subperíodo da análise, como se compõem as exportações de cada país em termos da classificação quaternária: Situação Ótima, Vulneráveis, Oportunidades Perdidas e em Retirada. Os Gráficos 2 e 3, a seguir, permitem uma observação rápida sobre o padrão de exportações argentino e brasileiro, mediante estática comparativa.

Se analisarmos de maneira conjunta os resultados da Matriz de Competitividade Argentina e Brasileira para o período de estudo da pesquisa podemos obter algumas conclusões relevantes. Assim, agrupando os mercados MUNDO e OCDE por um lado e Mercosul e AD por outro, resta evidente que há algumas diferenças importantes entre ambas as matrizes de competitividade. Em primeiro lugar, visualiza-se que Argentina manteve um padrão de inserção externa mais especializado em grupos Competitivos que em grupos Dinâmicos ${ }^{13}$, independentemente do mercado de referência. Isto quer dizer que a Argentina, de alguma maneira, não adequou seu perfil de especialização com relação à demanda dos grupos que se dinamizaram, mas construiu seu padrão de exportação a partir dos grupos nos quais ela conseguiu ser competitiva ${ }^{14}$.

(13) Dinâmicos são os grupos em situação ótima e oportunidades perdidas; Competitivos são aqueles em situação ótima e vulneráveis.

(14) Recursos Naturais, Energia e Manufaturas baseadas em Recursos Naturais. 
Por sua vez, o Brasil manteve uma especialização diferenciada segundo os mercados. Aos destinos MUNDO e OCDE sua especialização foi em grupos Competitivos, mais do que em Dinâmicos. Por outro lado, para os destinos Mercosul e AD a especialização brasileira se concentrou mais nos grupos Dinâmicos que nos Competitivos, com algumas exceções ${ }^{15}$.

Apesar disso, a Matriz de Competitividade da Argentina apresenta algumas mudanças de tendência durante os últimos anos. Para os destinos MUNDO, OCDE e AD os grupos Dinâmicos passaram a superar os Competitivos a partir de 2007. Isto já acontecia para o Mercosul desde 2000. Este aspecto é muito importante já que evidencia os impactos positivos do Mercosul sobre a estrutura de demanda da Argentina, sem dúvida o mercado mais benéfico do ponto de vista da qualidade da demanda pelas exportações desse país.

Outro elemento de relevância destes dados é que as matrizes de ambos os países alcançaram, para os mercados MUNDO e OCDE, o pior resultado entre 1990 e 2000, e o melhor resultado entre 2007 e 2010 (sendo que para a Argentina com destino MUNDO o melhor resultado é entre 2000-2007). Algo similar ocorreu com o destino AD, já que tanto a Matriz de Competitividade argentina como a brasileira apresentaram uma configuração mais positiva no subperíodo 2000-2007, e mais negativa em 2007-2010.

As matrizes brasileira e argentina apresentaram uma diferença no tocante ao destino Mercosul. Os melhores subperíodos para a matriz argentina foram os de 1985-1990 e 20072010. Já para o Brasil, foi o de 1990-2000. No subperíodo 2000-2007 ambas exibiram evolução semelhante.

Analisando conjuntamente os resultados das matrizes de competitividade para os dois mercados dos países emergentes (Mercosul e AD), poderíamos concluir que o Mercosul funciona como um "mercado de refúgio" nos períodos de crise, tanto para a Argentina como para o Brasil. Nos períodos mais complicados do comércio internacional, este mercado continua respondendo de forma positiva, prossegue melhorando a estrutura das exportações. Em contrapartida, o mercado da $\mathrm{AD}$ não responde dessa forma, apresenta outra dinâmica, menos benéfica e mais parecida com a da OCDE. A consequência disso é que a Matriz de Competitividade argentina e brasileira melhora na fase ascendente do ciclo e piora na fase descendente. Esse fato confirma a ideia estruturalista de que a estrutura produtiva e exportadora importa para o crescimento e desenvolvimento. Também, de que uma inserção externa baseada no aproveitamento dos recursos naturais traz vulnerabilidade para às economias, seja no curto prazo ou num prazo maior. Bekerman et al expressam que se não forem enfrentados corretamente os desafios que a China traz para América Latina (reprimarizção das exportações locais e pressão competitiva das exportações chinesas), os países da região podem aumentar a vulnerabilidade externa estrutural. (2014, p. 55)

Apesar dessa diferença, há um aspecto comum das matrizes para esses dois mercados emergentes, que importa ressaltar: desde 2007 cresceram de forma significativa as

(15) No subperíodo 2000-2007 para o Mercosul e na fase 1990-2000 para a AD. 
Oportunidades Perdidas. Isso evidencia que as estruturas exportadoras da Argentina e do Brasil não acompanharam a demanda crescente desses mercados emergentes. É possível que os processos de dinamização da demanda doméstica tenham gerado uma concorrência pela utilização da estrutura produtiva local, no curto prazo, o que acabou restringindo a expansão dessas exportações. O caso é ainda mais evidente para a matriz argentina destino Mercosul, já que a ascensão das Oportunidades Perdidas se inicia no subperíodo anterior. Os principais resultados para a Argentina são apresentados no Gráfico 2.

Gráfico 2

Matriz de Competitividade Argentina 1985-2010 (por destino, em \% das exportações no ano final)

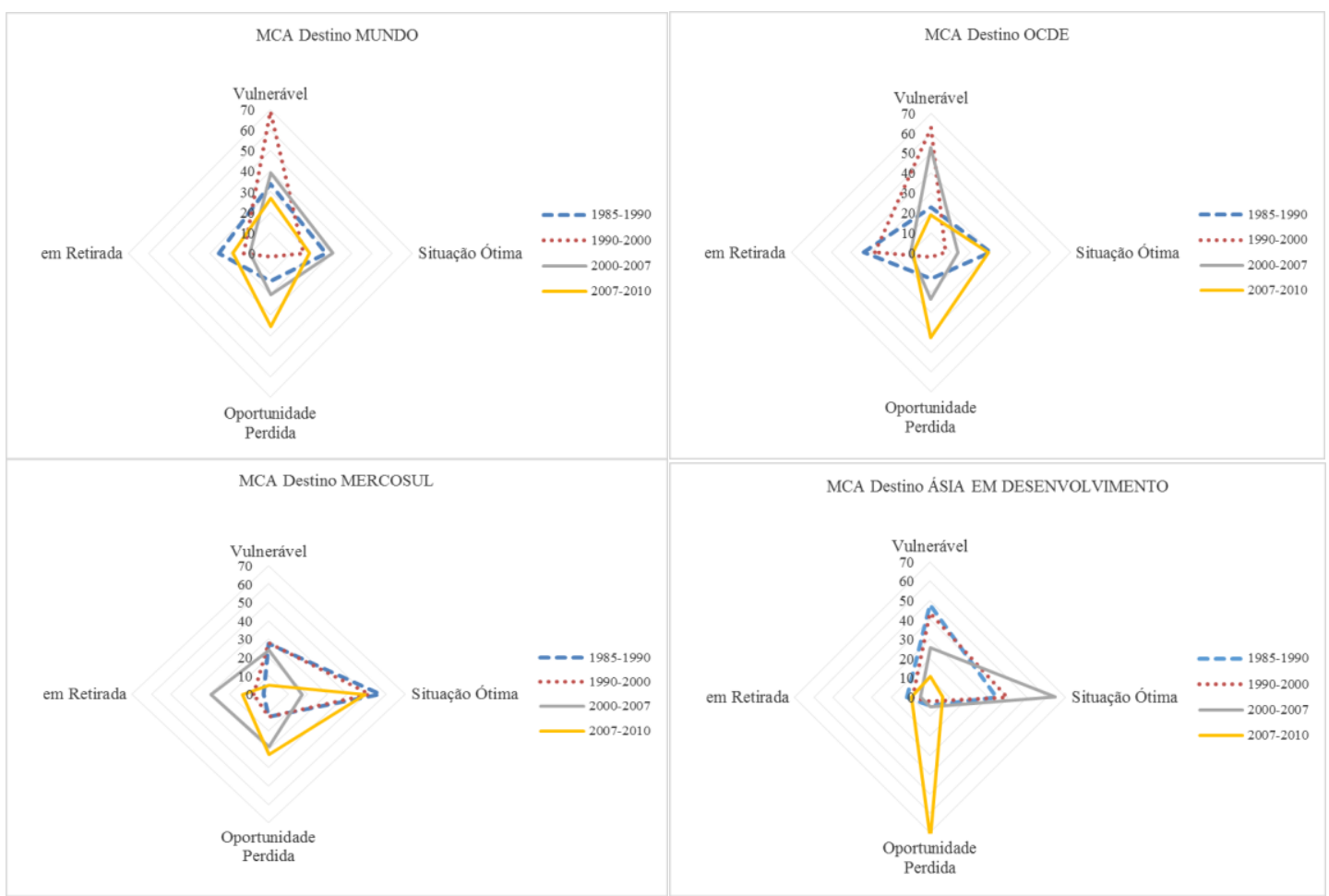

Fonte: Elaboração própria em base a TradeCAN (2012), Cepal. Nações Unidas.

Para o destino MUNDO a preponderância dos grupos Vulneráveis e em Retirada mostram que Argentina tem um perfil de exportações em grupos cuja demanda está decrescendo, isto é, uma grande proporção de suas exportações é em grupos poucos dinâmicos. O pior período é o que se estende entre 1990 e 2000, quando o país concentrou quase $70 \%$ de suas exportações em grupos Vulneráveis. Apesar disso, verifica-se uma melhora entre os subperíodos 1990-2000 e 2000-2007, nos quais aumentou a participação das exportações em Situação Ótima e se reduziram as em Retirada e Vulneráveis. No entanto, o aumento das Oportunidades Perdidas mostra que o país poderia ter ampliado o espaço em alguns mercados que se dinamizaram. Este processo fica ainda mais evidente entre 2007 e 2010, já que as 
Oportunidades Perdidas ultrapassaram um terço do total exportado. Apesar disso, este foi o único período em que as exportações dinâmicas superaram as não dinâmicas.

Para o destino OCDE visualiza-se uma péssima situação, já que a composição das exportações se concentrou em setores cuja demanda estava decrescendo, isto é, grupos Vulneráveis e em Retirada. E embora no subperíodo de 1985 a 1990, as exportações de grupos dinâmicos tenham ganho um espaço significativo, alcançando $43 \%$ das exportações totais, essas exportações tornaram-se ainda mais expressivas entre 2007 e 2010, alcançando quase três quartos das exportações totais.

As exportações de grupos Vulneráveis foram muito elevadas em 1990 (63\%) e em 2000, superando 50\% das exportações. Essa caracterização tem vínculo direto com a estrutura de exportações à OCDE, que concentrou quase $75 \%$ em bens primários (manufaturados ou não).

Por outro lado, é importante destacar que no período de 2007 a 2010 a MC modificouse radicalmente. Em particular, as Oportunidades Perdidas representavam quase $43 \%$ das exportações, e as em Situação Ótima, 29\%. Vale mencionar que as mudanças desde 2007 não significaram variações substantivas no padrão de exportações da Argentina. O que ocorreu foi o crescimento da demanda da OCDE por bens primários e alimentos ${ }^{16}$.

Para o destino Mercosul os radiais mostram que em torno de $50 \%$ das exportações estavam em Situação Ótima, e aproximadamente três quartas partes das mesmas eram de grupos dinâmicos (sendo tais participações maiores entre 2007 e 2010) ${ }^{17}$. É muito provável que entre 2000 e 2007 o expressivo aumento da demanda do Mercosul por MnoBRN não tenha sido absorvido pela oferta da Argentina, dado o aumento das Oportunidades Perdidas, que passaram de $12 \%$ das exportações em 1985 e 1990 para quase $29 \%$. Isso revela as dificuldades que a Argentina teve para adaptar sua estrutura industrial e a oferta de bens para exportação à crescente demanda mundial. Além disto, há indícios de que outros países competidores deste mercado ganharam espaço no Mercosul.

É importante sublinhar que a participação de mercado da Argentina no Mercosul cresceu até 2000 , alcançando o valor máximo de $9,11 \%$ e, a partir de então, apresentou uma drástica redução. Dois países ganharam espaço mais forte no Mercosul a partir de 2000, Brasil e China. Esses três países juntos somam mais de um quarto das exportações para este destino. A Argentina participava com mais da metade destas exportações em 1990, mas reduziu sua quota de mercado a menos de um quarto em 2010. Por sua vez, as exportações do Brasil representavam $42 \%$ e as da China $7 \%$ em 1990; em 2010, participavam com 30\% e 48\%, respectivamente. Destarte, o Brasil ganhou espaço com relação à Argentina neste mercado, e é a China o principal rival de ambos.

(16) Esse é outro exemplo de que, ainda hoje, a demanda da OCDE por bens relacionados a recursos naturais não apresenta tendência decrescente.

(17) Isto com exceção do subperíodo 2000-2007, quando as exportações em Situação Ótima eram apenas 17\% e as de grupos dinâmicos de $46 \%$. 
Finalmente, para o destino Ásia em Desenvolvimento, a MC caracterizou-se pela expressiva composição de exportações em grupos em que a Argentina era competitiva, isto é, em grupos nos quais ganhou participação de mercado, independentemente de os grupos serem ou não dinâmicos. A MC mantém-se quase idêntica nos dois primeiros momentos analisados, quando os grupos Vulneráveis superaram os de Situação Ótima, e juntos concentraram mais de $80 \%$ das exportações. No subperíodo 2000-2007, esses grupos concentraram mais de $90 \%$ das exportações argentinas, invertendo-se apenas a ordem. Entretanto, o subperíodo 2007-2010 se caracterizou por uma forte expansão em Oportunidades Perdidas, que absorveu uma intensa redução das exportações de Situação Ótima. Os grupos pouco dinâmicos (Vulneráveis e em Retirada) foram preponderantes até 2000 , porém mantiveram uma tendência decrescente (apenas 18\% das exportações em 2010). Os principais resultados para o Brasil são apresentados no Gráfico 3.

Gráfico 3

Matriz de Competitividade Brasil 1985-2010 (por destino, em \% das exportações no ano final)

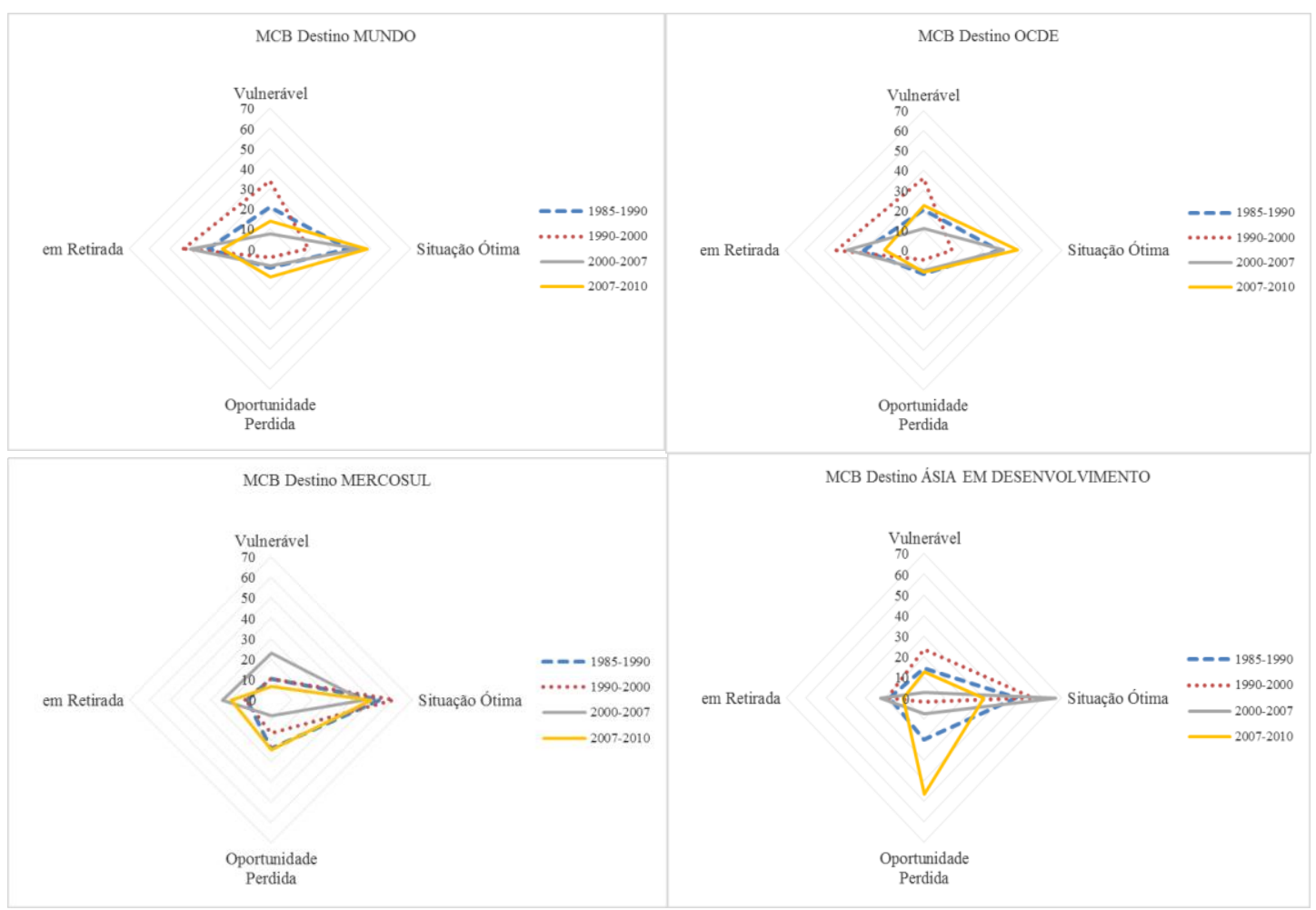

Fonte: Elaboração própria em base a TradeCAN (2012); Cepal; Nações Unidas.

Os destinos MUNDO e OCDE são apresentados em conjunto por terem matrizes muito semelhantes. Aproximadamente metade das exportações são de grupos dinâmicos e competitivos. Apesar de que entre 1985 e 1990 as Situações Ótimas tenham sido relevantes, houve uma piora durante a década de 1990 , quando o país concentrou quase $80 \%$ das suas 
exportações em grupos não dinâmicos (Vulneráveis e em Retirada). A partir de 2000 os grupos em Situação Ótima ganharam espaço e no último subperíodo os grupos dinâmicos e competitivos ascenderam a $62 \%$ das exportações para o MUNDO e até quase $60 \%$ e $70 \%$ das exportações para os países industrializados, respectivamente. As Oportunidades Perdidas não têm se mostrado muito significativas nesses mercados, motivo pelo qual o Brasil não estaria perdendo participação de mercado nos grupos em que se especializa.

Para o destino Mercosul, os radiais mostram que em torno de $50 \%$ das exportações estavam em Situação Ótima, e aproximadamente três quartas partes eram de grupos dinâmicos (sendo tais participações maiores até 2000) ${ }^{18}$. Entre 2000 e 2007, à diferença do que ocorreu com a Argentina, as Oportunidades Perdidas foram muito baixas, na verdade, as menores do período analisado. Não obstante, os grupos Vulneráveis e em Retirada duplicaram a participação, e entre ambos ascenderam a $47 \%$ das exportações em grupos não dinâmicos. Em decorrência disso fica claro que, embora o Mercosul seja o melhor mercado para a Argentina e o Brasil, os resultados em conjunto da MC argentina e brasileira demonstraram que o subperíodo 2000-2007 foi relativamente o que trouxe menos benefícios para ambas as economias. Ou seja, confirma-se que o Mercosul é um mercado de refúgio dessas economias e que outorga mais estabilidade que os outros mercados.

Finalmente, entre 2007 e 2010, houve um grande crescimento das Oportunidades Perdidas, que absorveu a queda dos grupos Vulneráveis, e um pequeno acréscimo das Situações Ótimas, que absorveu a queda dos grupos em Retirada. Neste último momento, quase $74 \%$ das exportações foram de grupos dinâmicos e $56 \%$ de grupos competitivos. Isto expressa a melhora na quota de mercado do Brasil com relação à Argentina num primeiro momento, mas que foi relativizada pela ascensão da China nas importações do Mercosul.

Em termos de trajetória, pode se dizer que a MC destino Mercosul se manteve quase idêntica entre o primeiro e o segundo subperíodo; regrediu para uma situação com maior presença de grupos pouco dinâmicos, entre 2000 e 2007; e melhorou para uma matriz com maior participação de grupos dinâmicos no período mais recente. Porém, os resultados finais não conseguem superar os impactos sofridos pelo padrão de exportações entre 1990-2000.

Para o destino Ásia em Desenvolvimento a MC caracterizou-se pela expressiva composição de exportações em grupos em que o Brasil era dinâmico e competitivo, isto é, em grupos nos quais o país ganhou participação de mercado e cuja demanda estava crescendo. As exportações em Situação Ótima foram sempre relevantes e ganharam participação até o subperíodo 2000-2007, alcançando dois terços das exportações totais. Porém, no subperíodo seguinte estas caíram para menos da metade. Também entre 2007-2010, as Oportunidades Perdidas cresceram em grande escala, alcançando $47 \%$ das exportações.

(18) Com exceção do subperíodo 2000-2007, quando as exportações em Situação Ótima eram de 45\% e as de grupos dinâmicos de $53 \%$. 
Virginia Laura Fernández, Marcelo Luiz Curado

Em termos do caminho seguido pela MC destino AD, verifica-se que até 2000-2007 as exportações em Situações Ótimas conseguiram melhorar ininterruptamente e alcançar seu patamar mais elevado. Porém, na última fase de análise, esses grupos regrediram em grande proporção, simultaneamente à escalada das Oportunidades Perdidas.

\section{Algumas reflexões sobre o uso da Matriz de Competitividade de Fajnzylber e Mandeng}

Inicialmente, na pesquisa de Fajnzylber e Mandeng, a MC foi construída com relação a apenas um mercado (OCDE) e um período (1979/1988). Os resultados confirmavam a hipótese que o Brasil apresentava uma exportação mais dinâmica e de manufaturas mais sofisticadas, e que as exportações argentinas eram menos dinâmicas, com forte presença de recursos naturais. A discussão de fundo era a dependência dos países latino-americanos à exportação de recursos naturais e commodities em geral. Neste sentido, inclusive, previam que a OCDE diminuiria a demanda por esses bens de baixo valor agregado, o que impactaria nas economias nacionais.

Esta pesquisa, ao resgatar essa metodologia cepalina, inova ao construir diversas matrizes, tendo como foco vários mercados e períodos. Isso permite analisar a evolução das MC e comparar diversos mercados, enriquecendo o debate e possibilitando análises até então inéditas no âmbito da metodologia utilizada. As matrizes apresentadas neste trabalho permitem visualizar mudanças relevantes na estrutura da demanda dos mercados e na estrutura comercial de ambos os países analisados. De fato, verificam-se mudanças específicas nas MC da Argentina e do Brasil, confirmando uma alteração nos termos de troca dos países latinoamericanos, causada, sobretudo, pela dinamização da demanda por commodities (alimentos, energia, e minerais e metais) no início do século XXI.

Neste sentido, embora Fajnzylber não tenha antecipado o crescimento da demanda por commodities e bens primários, isso não impossibilitou que as MC ora apresentadas visualizem a ocorrência de uma mudança estrutural, seja do lado do mercado, seja do lado da estrutura produtiva. É notável que a evolução da demanda crescente por Recursos Naturais, Energia e Manufaturas Baseadas em Recursos Naturais a partir do ano 2000 tenha modificado a forma das MC de tal modo que os grupos em que antes a Argentina e o Brasil eram competitivos, mas não dinâmicos (Vulneráveis), passaram a ser competitivos e ou dinâmicos (Situação Ótima ou Oportunidade Perdida). Mudanças estruturais, como a verificada nesta pesquisa, são facilmente identificadas por meio das MC, e nisto consiste grande parte de sua relevância como ferramenta de análise. Em outras palavras, a matriz de competitividade é um instrumento que identifica as mudanças estruturais nos padrões de consumo, produção e comércio internacional. Entretanto, as conclusões que a MC permite são limitadas pela necessidade de se caracterizar extensivamente a estrutura de mercado e a comercial. Ou seja, os losangos não mostram a "qualidade" das exportações, mas apenas como certo país reagiu à mudança da demanda de certo mercado. 
Essa limitação analítica da MC se mostrou, neste estudo, no fato de que ela, por si só, não revela que os grupos vulneráveis das exportações argentinas se constituem quase exclusivamente pelo complexo oleaginoso ou de commodities no geral. É dizer, o que os losangos mostram precisa ser qualificado por informações sobre a demanda do mercado analisado e, sobretudo, do conjunto das exportações. De fato, a metodologia pode insinuar que um mercado é vantajoso por ter grande expansão de grupos em Situação Ótima, mas que se referem a atividades cuja demanda foi, historicamente, vulnerável, como no caso do complexo oleaginoso, mineiro ou petrolífero.

Esse problema da MC nos coloca diante de outro. A demanda por recursos naturais, cuja previsão de Fajnzylber era de queda, pode se manter estável, ou até mesmo crescente, em razão da emergência de novos mercados. Neste cenário, a exportação de recursos naturais e energia tem outro efeito e coloca outras questões, distintas da apresentada pelo autor. Essas questões, em verdade, sintetizam a dualidade que emerge de grande parte das economias latinoamericanas, cujos padrões de inserção externa se baseiam fortemente nos recursos naturais. Contudo, o que se mostra indubitável é que este século iniciou com uma mudança radical na estrutura da demanda mundial, com reflexos claros nas exportações argentinas e brasileiras.

\section{Conclusões}

Iniciamos esta pesquisa interessados na relação entre a matriz produtiva argentina e brasileira e o padrão de exportações desses países. Foi a partir da leitura da obra de Fajnzylber que decidimos analisar a inserção externa da Argentina e do Brasil, focando na competitividade de seus produtos exportados. Entendemos que a análise da competitividade não é um fim em si mesmo, mas um instrumento para verificar as relações entre a evolução da demanda de certo mercado e o padrão de exportações de um país, com o objetivo de orientar suas políticas econômicas e possibilitar, assim, a melhora da sua estrutura produtiva e seu desenvolvimento econômico e social.

O pano de fundo de nossa pesquisa foi a condição histórica desses países de exportadores de recursos naturais ou manufaturas com baixo valor agregado. De fato, o boom das commodities, no início do século XXI, em especial a demanda asiática por soja e ferro e seus derivados, colocou a política econômica argentina e brasileira em xeque. Por outro lado, a crescente interação produtiva e comercial entre Argentina e Brasil, do Complexo Automotivo e de Autopeças, teve o condão de dinamizar o parque industrial de ambos os países, trazendo, além de dilemas à condução da política comercial, uma oportunidade de diversificar e sofisticar as suas matrizes produtivas. Foi, portanto, tendo em conta esse debate e as questões e dilemas a ele concernentes, que a atual pesquisa se desenvolveu. Vale destacar que as discussões mais recentes sobre comércio internacional se focam nos desafios que a ascensão da China traz para as estruturas produtivas da Argentina e do Brasil. A reprimarização das economias regionais e a concorrência pelas exportações chinesas sintetizam a armadilha da região com relação à China (Altamonte; Sánchez, 2016; Berkerman et al., 2014; Hiratuka 
et al., 2012). Por fim, as discussões também revelam os benefícios gerados pelo comércio mais qualificado gerados no âmbito do Mercosul (Berrettoni, 2013; Nonnenberg; Mesentier, 2011).

Os resultados obtidos com o desenvolvimento das Matrizes de Competitividade (MC) demonstram que os países emergentes (analisados através da Ásia em Desenvolvimento (AD) e do Mercosul) foram determinantes na evolução do padrão de exportações da Argentina e do Brasil, nas últimas três décadas. Isso ocorreu de tal modo que as exportações para os países da $\mathrm{AD}$ e para o Mercosul foram totalmente reconfiguradas, imprimindo força sobre as estruturas produtivas argentina e brasileira. Além disso, verificou-se que o padrão de exportação para AD evoluiu no sentido de conceder mais participação aos Recursos Naturais (RN). Os dados de Hiratuka et al (2012, p. 120) confirmam que as exportações argentinas para a China direcionaram-se majoritariamente para produtos primários e manufaturas baseadas em recursos naturais ${ }^{19}$. Em contrapartida, o Mercosul foi o único mercado que abriu espaço para os produtos argentinos e brasileiros de maior valor agregado, Manufaturas não Baseadas em Recursos Naturais (MnoBRN). Nonnenberg e Mesentier confirmam que houve uma elevação da intensidade tecnológica das exportações intrarregionais de Brasil e Argentina entre $1991 \mathrm{e}$ 2009, e que essa elevação está fortemente correlacionada com o crescimento da participação dos produtos da cadeia automobilística (2011, p. 28).

Por outro lado, se analisarmos de maneira conjunta os resultados da MC argentina e brasileira, para o período em estudo, ressaltam-se algumas diferenças importantes. Em primeiro lugar, visualiza-se que a Argentina mantém um padrão de inserção externa mais especializado em grupos Competitivos (Situação Ótima e Vulneráveis) que em Dinâmicos (Situações Ótimas e Oportunidades Perdidas), independentemente do mercado de referência. Isso quer dizer que a Argentina, de alguma maneira, não adequa seu perfil de especialização com relação à demanda dos grupos que estão se dinamizando, mas constrói sua estrutura de exportação a partir dos grupos nos quais ela consegue ser competitiva (embora essa tendência tenha mudado a partir de 2000 para o Mercosul e, desde 2007, para os outros mercados quando, os grupos Dinâmicos passam a superar os Competitivos).

Por sua vez, o Brasil mantém uma especialização diferenciada orientada a cada mercado. Aos destinos MUNDO e OCDE sua especialização é em grupos Competitivos, mais do que em Dinâmicos. Por outro lado, aos destinos Mercosul e AD, a especialização brasileira se concentra mais nos grupos Dinâmicos que nos Competitivos, com algumas exceções.

Numa visão geral, podemos afirmar que as MC de ambos os países, com relação ao Mercosul, são as mais estáveis e, embora apresentem algumas variações, concentram a maior parte das exportações em Situações Ótimas. Por sua vez, as MC com destino AD também apresentam certa similaridade entre períodos, ainda que o aumento das Oportunidades Perdidas

(19) Em 2008, ano em que previamente à crise o comércio internacional foi mais estável, os grupos "sementes e frutos oleaginosos" e gorduras e azeites vegetais conglomeram 77,5\% das exportações argentinas à China. O mesmo aconteceu com o Brasil, que concentrou suas exportações à China em produtos básicos do complexo oleaginoso e mineiro, ocasião em que os quatros primeiros grupos deste complexo concentraram 84\% das exportações (em 2009). (Ibid, 2012, p. 108). 
modifique a forma dos últimos radiais. A grande expansão dos mercados emergentes no início do século XXI, como foi dito, dificultou às economias brasileira e argentina a possibilidade de expandir sua oferta produtiva e exportável, gerando a perda de oportunidades nos grupos em que historicamente se especializaram: complexo automotivo para o Mercosul, e complexo soja e de minério de ferro para a Ásia em Desenvolvimento. Para aprofundar a análise, é imprescindível identificar e discorrer sobre os dez primeiros grupos de exportação da Argentina e do Brasil a cada mercado, mas por questões de espaço isso é impossível neste artigo.

Finalmente, da análise conjunta dos resultados das matrizes de competitividade para os dois mercados dos países emergentes (Mercosul e AD), poderíamos concluir que o Mercosul funciona como um mercado de refúgio nos períodos de crise tanto para a Argentina como para o Brasil. Nos períodos mais complicados do comércio internacional, esse mercado continua respondendo de forma positiva, melhorando a estrutura das exportações. Em contrapartida, o mercado da $\mathrm{AD}$ não responde dessa forma, apresenta outra dinâmica, menos benéfica e mais parecida com a da OCDE. A consequência disso é que a matriz de competitividade argentina e brasileira melhora na fase ascendente do ciclo e piora na fase descendente.

\section{Referências bibliográficas}

ALTAMONTE, H.; SÁNCHEZ, R. Hacia una nueva gobernanza de los recursos naturales en América Latina y el Caribe Santiago de Chile: Cepal. Naciones Unidas, mayo 2016.

BALTAR, C.; PRATES, D. O desempenho das exportações brasileiras e chinesas após a crise de 2008-2009. Campinas: Unicamp. IE. Núcleo de Economia Industrial e da Tecnologia. jan./abr. 2014. (Boletim NEIT, n. 27).

BALASSA, B. Trade liberalization and "revealed" comparative advantage. The Manchester School, v. XXXIII, n. 2, p. 99-123, 1965.

BASUALDO, E. M. Estudios de historia económica argentina: desde mediados del siglo XX a la actualidad. 2. ed. Buenos Aires: Siglo XXI Editores, 2013.

BEKERMAN, M.; DALMASSO, G. Políticas productivas y competitividad industrial. El caso de Argentina y Brasil. Revista de Economia Política, v. 34, n. 1 (134), p. 158-180, jan./mar. 2014.

BERRETTONI, D. América Latina en las exportaciones argentinas: la importancia del mercado regional en la calidad de la inserción internacional. Revista Argentina de Economía Internacional, Centro Economía Internacional, Ministerio de Relaciones Exteriores y Culto de la República Argentina, n. 2, p. 17-40., dic. 2013.

BIELSCHOWSKY, R. Cincuenta años de la Cepal: una reseña. Fondo de Cultura Económica, 1998.

BIELSCHOWSKY, R. (Compl.). Sesenta años de la Cepal: textos seleccionados del decenio 1998-2008. Buenos Aires: Siglo XXI Editores, 2010. 
Virginia Laura Fernández, Marcelo Luiz Curado

BITTENCOURT, G. (Coord.). El Impacto de China en América Latina: comercio e inversiones. Montevideo: Red Mercosur de Investigaciones Económicas, 2012.

CARNEIRO, R. Commodities, choques externos e crescimento: reflexões sobre a América Latina. División de Desarrollo Económico, Cepal, Naciones Unidas, ene. 2012. (Serie Macroeconomía del Desarrollo, n. 117).

CUNHA, A.; LÉLIS, M.; BICHARA, J. O Brasil no espelho da China: tendências para o período pós-crise financeira global. Revista Economia Contemporânea, Rio de Janeiro, v. 16, n. 2, p. 208-236, maio/ago. 2012.

CASTRO, Antônio Barros de. No espelho da China. Disponível em: http://www.desenvolvimentistas.com.br/desempregozero/wpcontent/uploads/2008/02/noespelho-da-china1.pdf. Accessed: July 13, 2017.

CEPAL. Guía de Usuario TradeCAN, 2012a.

CEPAL. Guía de Ejercicios TradeCAN, 2012b.

CIMOLI, M.; ROVIRA, S. Elites and structural inertia in Latin America: an introductory note on the Political Economy of Development. Journal of Economic Issues, v. XLII, n. 2, Jun. 2008 .

CIMOLI, M.; PORCILE, G. Technology, heterogeneity and growth: a structuralist toolbox. . October, 2011. (MPRA Paper, n. 33801). Disponível em: https://mpra.ub.unimuenchen.de/33801/.

CYPHER J. M. South America's commodities boom: developmental opportunity or path dependent reversion? Canadian Journal of Development Studies, v. 30, n. 3-4, p. 635-662, 2010 .

CURADO, M. China rising. Threats and opportunities for Brazil. Latin American Perspectives, v. 42, n. 6 (205), p. 88-104, Nov. 2015.

DIAMAND, M. La estructura productiva desequilibrada Argentina y el tipo de cambio. Desarrollo Económico, Argentina, v. 12, n. 45, 1972.

DUSSEL PETERS, E. Políticas Chinas de comercio exterior e inversión extranjera y sus efectos. In: BITTENCOURT (Coord.). El impacto de China en América Latina: Comercio e Inversiones. RED Mercosur de Investigaciones Económicas, Uruguay, 2012.

FAJNZYLBER, F. Reflexiones sobre la industrialización exportadora del sudeste asiático. Revista de la CEPAL, Santiago de Chile, n. 15, p. 117-138, 1981.

FAJNZYLBER, F. La industrialización trunca de América Latina. México: Editorial Nova Imagem, 1983.

FAJNZYLBER, F. Competitividad internacional: evolución y lecciones. Revista de la Cepal, n.36, p. 7-24, dic. 1988. 
FAJNZYLBER, F. Industrialización en América Latina: de la "caja negra” al "casillero vacío". 1989. In: TORRES OLIVOS, M. (Compl.). Fernando Fajnzylber: una visión renovadora del desarrollo en América Latina. Santiago de Chile: Cepal Editora. Naciones Unidas, nov. 2006. FAJNZYLBER, F. Inserción internacional e innovación institucional. Revista de la Cepal, n. 44, p. 149-178, ago. 1991.

FERRER, A. Raúl Prebisch y el dilema del desarrollo en el mundo global. Revista de la Cepal, n. 101, ago. 2010.

FERRER, A. Historia de la globalización: los orígenes del orden económico mundial. Buenos Aires: Fondo de Cultura Económica, 1996.

FERRER, A. La economía Argentina. Las etapas de du desarrollo y problemas actuales. Fondo de Cultura Económica, 1973.

FURTADO, C. Desarrollo y subdesarrollo. Rio de Janeiro: Editora Fundo de Cultura, 1961.

FURTADO, C. Formação econômica do Brasil. São Paulo: Companhia Editora Nacional, 2001. (1. ed., 1959).

HERMIDA, C.; XAVIER, C.; COSTA, G. Fragmentação internacional da produção, cadeias globais de valor e crescimento económico: uma nova abordagem empírica. In: ENCONTRO NACIONAL DE ECONOMIA,44, Anpec, Foz de Iguazú, Brasil, 2016.

HIRATUKA, C. Inserção comercial brasileira frente às transformações na economia global: desafios pós-crise. In: BARBOSA, N.; MARCONI, N.; PINEIRO, M.; CARVALHO, L. (Orgs). Indústria e Desenvolvimento Produtivo no Brasil. Ed. 1, Elsevier/FGV, 2015. v. 1, p. 295-334.

HIRATUKA, C.; CASTILHO, M.; DUSSEL PETERS, E.; BIANCO, C.; CARRACELAS, G. Relações comerciais entre América Latina e China: caracterização da evolução recente. In: BITTENCOURT (Coord.). El impacto de China en América Latina: comercio e inversiones. Uruguay: Red Mercosur de Investigaciones Económicas, 2012.

HIRATUKA, C.; SARTI, F. Transformações na estrutura produtiva global, desindustrialização e desenvolvimento industrial no Brasil. Revista de Economia Política, v. 37, n. 1, p. 189-207, 2017.

KATZ, J.; DUSSEL PETERS, E. Diferentes estrategias en el nuevo modelo económico latinoamericano: importaciones temporales para su reexportación y transformación de materias primas. 2002. Mimeo,

MAGEE, S. Prices, incomes, and foering trade. In: KENEN, P.B. (Comp.). International trade and finance. Cambridge, Mass.: Cambridge University Press, s.d. 
Virginia Laura Fernández, Marcelo Luiz Curado

MANCINI, M. Tendencias actuales y transformaciones incipientes en China: sus implicancias para las economías latinoamericanas. Revista Entrelíneas de la Política Económica, Universidad Nacional de La Plata, La Plata, v. 7, n. 40, p. 12 -21, dic. 2014.

MANDENG, O. J. Análisis de competitividad: Argentina: estudio de caso basado en el programa computacional CAN. Indicadores Econômicos FEE. Análise Conjuntural, v. 21, n. 2, p. 189-203, ago. 1993.

MANDENG, O. J. Competitividad internacional y especialización. Revista de la Cepal, n. 45, p. 25-42, dic. 1991a.

MANDENG, O. J. Metodología para un análisis de la competitividad internacional de los países . Industrialización y Desarrollo Tecnológico, n. 10, p. 7-10, ago. 1991 b.

MÓDOLO, D.; HIRATUKA, C. Impacto da concorrência chinesa em terceiros mercados: uma análise por regiões e por categorias tecnológicas. Campinas: Unicamp, 2014.

NONNENBERG, M. J. B. Exportações e inovação: uma análise para América Latina e SulSudeste da Ásia. Brasília: Ipea, 2011. (Textos para Discussão).

NONNENBERG, M. J. B.; MESENTIER, A. A criação do Mercosul contribuiu para aumentar a intensidade tecnológica das exportações da região? Brasília: Ipea, 2011. (Textos para Discussão, n. 1644).

PEREZ, C. Una visión para América Latina: dinamismo tecnológico e inclusión social mediante una estrategia basada en los recursos naturales". Globelics, jul. 2005. (Working Paper Series, n. 08-04)

PREBISCH, R. El desarrollo económico de América Latina y alguno de sus principales problemas. Boletín Económico de América Latina, v. 7, feb. 1962. (1. ed., 1949).

RAMOS, J. Una estrategia de desarrollo a partir de complejos productivos en torno a los recursos naturales. Revista de la Cepal, Santiago de Chile, n. 66, p. 105-125, dic. 1998.

RAPOPORT, M. Historia económica, política y social de la Argentina (1880-2003). 6. ed. Buenos Aires: Emecé Editores S.A., ago. 2013.

RODRIGUEZ, O. El estructuralismo latinoamericano. México: Siglo XXI Editores/Cepal, 2006.

XAVIER, C. Padrões de especialização e saldos comerciais no Brasil. Apresentado na Anpec, Faculdades de Valinhos, Valinhos, 2001.

XAVIER, C. Padrões de especialização e competitividade no comércio exterior brasileiro. Tese (Doutoramento)-Universidade Estadual de Campinas, Campinas, São Paulo, 2000. 


\section{Anexo 1}

Tabelas com estruturas de mercados.

MUNDO, OCDE, Mercosul e Ásia em desenvolvimento e estrutura comercial da argentina e do Brasil para cada mercado (TradeCAN, 2012)

Tabela 1

Estrutura de mercado (importações por destinos)

\begin{tabular}{|c|c|c|c|c|c|c|c|c|c|c|}
\hline \multirow{2}{*}{$\begin{array}{c}\text { Participação setorial em } \\
\%\end{array}$} & \multicolumn{5}{|c|}{ MUNDO } & \multicolumn{5}{|c|}{ OCDE } \\
\hline & 1985 & 1990 & 2000 & 2007 & 2010 & 1985 & 1990 & 2000 & 2007 & 2010 \\
\hline Recursos Naturais & 16,33 & 14,54 & 10,31 & 10,43 & 11,34 & 16,11 & 14,56 & 10,48 & 10,18 & 10,98 \\
\hline Agricultura & 13,40 & 11,96 & 8,81 & 7,91 & 8,71 & 13,27 & 12,17 & 9,15 & 8,42 & 9,39 \\
\hline $\begin{array}{l}\text { Fibras Têxtil, Minerais e } \\
\text { Metais }\end{array}$ & 2,93 & 2,58 & 1,51 & 2,52 & 2,63 & 2,84 & 2,39 & 1,32 & 1,75 & 1,59 \\
\hline Energia & 17,35 & 9,71 & $\mathbf{9 , 3 1}$ & 10,21 & $\mathbf{9 , 9 3}$ & 17,82 & $\mathbf{9 , 7 8}$ & 8,94 & 10,57 & 10,35 \\
\hline Manufaturas & 64,86 & 73,98 & $\mathbf{7 7 , 8 5}$ & 71,77 & 70,05 & 64,54 & 73,82 & 77,48 & 71,47 & 69,51 \\
\hline Manufaturas RRNN & 5,67 & 5,79 & 4,78 & 5,02 & 4,78 & 5,89 & 5,85 & 4,75 & 4,81 & 4,16 \\
\hline Manufaturas Não RRNN & 59,19 & 68,20 & 73,07 & 66,74 & 65,28 & 58,66 & 67,97 & 72,72 & 66,66 & 65,35 \\
\hline Outros & 1,47 & 1,78 & 2,53 & 7,60 & 8,68 & 1,54 & 1,84 & 3,10 & $\mathbf{7 , 7 8}$ & 9,16 \\
\hline \multirow{2}{*}{$\begin{array}{c}\text { Participação setorial em } \\
\%\end{array}$} & \multicolumn{5}{|c|}{ Mercosul } & \multicolumn{5}{|c|}{ Ásia em Desenvolvimento } \\
\hline & 1985 & 1990 & 2000 & 2007 & 2010 & 1985 & 1990 & 2000 & 2007 & 2010 \\
\hline Recursos naturais & 16,97 & 15,41 & $\mathbf{9 , 5 2}$ & 7,74 & 7,16 & 16,01 & 13,10 & $\mathbf{9 , 3 7}$ & 10,50 & 12,00 \\
\hline Agricultura & 13,58 & 11,11 & 7,88 & 5,56 & 5,73 & 12,53 & 9,61 & 7,07 & 5,87 & 6,73 \\
\hline $\begin{array}{l}\text { Fibras Têxtil, Minerais e } \\
\text { Metais }\end{array}$ & 3,40 & 4,29 & 1,64 & 2,18 & 1,43 & 3,49 & 3,49 & 2,31 & 4,63 & 5,27 \\
\hline Energia & 34,12 & 23,18 & 11,54 & $\mathbf{9 , 9 2}$ & 7,91 & 14,81 & 8,82 & 11,50 & 10,36 & 10,26 \\
\hline Manufaturas & 48,83 & 61,33 & 78,80 & $\mathbf{7 3 , 5 0}$ & 77,60 & 67,75 & 76,80 & 78,30 & 72,41 & $\mathbf{7 0 , 1 8}$ \\
\hline Manufaturas RRNN & 2,90 & 3,31 & 2,71 & 3,05 & 2,56 & 4,89 & 6,26 & 5,61 & 5,84 & 6,53 \\
\hline Manufaturas Não RRNN & 45,93 & 58,02 & 76,09 & 70,46 & 75,04 & 62,86 & 70,54 & 72,69 & 66,57 & 63,65 \\
\hline Outros & 0,08 & 0,09 & 0,15 & 8,84 & 7,33 & 1,43 & 1,27 & $\mathbf{0 , 8 2}$ & 6,74 & 7,57 \\
\hline
\end{tabular}

Fonte: Elaboração própria em base a TradeCan (2012). Segundo a CUCI Rev. 2 reagrupada por Mandeng (1993, p. 190). 
Tabela 2

Estrutura comercial da argentina (exportações por destino)

\begin{tabular}{|c|c|c|c|c|c|c|c|c|c|c|}
\hline \multirow{2}{*}{$\begin{array}{c}\text { Participação setorial em } \\
\%\end{array}$} & \multicolumn{5}{|c|}{ MUNDO } & \multicolumn{5}{|c|}{ OCDE } \\
\hline & 1985 & 1990 & 2000 & 2007 & 2010 & 1985 & 1990 & 2000 & 2007 & 2010 \\
\hline Recursos Naturais & 68,83 & 59,41 & 49,10 & 59,49 & 55,94 & 71,64 & 67,41 & 60,76 & 69,55 & 65,52 \\
\hline Agricultura & 65,77 & 55,81 & 46,57 & 56,39 & 53,06 & 68,24 & 63,66 & 57,13 & 64,41 & 60,82 \\
\hline $\begin{array}{l}\text { Fibras Têxtil, Minerais e } \\
\text { Metais }\end{array}$ & 3,06 & 3,60 & 2,52 & 3,11 & 2,88 & 3,40 & 3,74 & 3,63 & 5,14 & 4,71 \\
\hline Energia & 6,38 & 6,49 & 17,86 & 7,50 & 7,53 & 6,32 & 5,10 & 12,44 & 5,79 & 5,85 \\
\hline Manufaturas & 24,13 & 33,64 & 32,41 & 32,55 & 36,09 & 21,09 & 26,81 & 25,35 & 23,99 & 27,64 \\
\hline Manufaturas RRNN & 6,99 & 7,25 & 5,01 & 3,79 & 5,07 & 7,72 & 9,12 & 7,90 & 5,54 & 9,78 \\
\hline Manufaturas Não RRNN & 17,15 & 26,38 & 27,40 & 28,77 & 31,01 & 13,37 & 17,69 & 17,45 & 18,45 & 17,86 \\
\hline Outros & $\mathbf{0 , 5 0}$ & 0,47 & 0,63 & 0,45 & 0,44 & $\mathbf{0 , 5 1}$ & 0,56 & 1,45 & 0,66 & 0,99 \\
\hline \multirow{2}{*}{$\begin{array}{c}\text { Participação setorial em } \\
\%\end{array}$} & \multicolumn{5}{|c|}{ Mercosul } & \multicolumn{5}{|c|}{ Ásia em Desenvolvimento } \\
\hline & 1985 & 1990 & 2000 & 2007 & 2010 & 1985 & 1990 & 2000 & 2007 & 2010 \\
\hline Recursos Naturais & 54,40 & 49,80 & 31,53 & 28,82 & 25,34 & 74,20 & 49,10 & 79,79 & 85,04 & 85,94 \\
\hline Agricultura & 52,37 & 48,03 & 30,01 & 27,37 & 24,55 & 70,68 & 40,94 & 75,39 & 80,73 & 81,19 \\
\hline $\begin{array}{l}\text { Fibras Têxtil, Minerais e } \\
\text { Metais }\end{array}$ & 2,03 & 1,77 & 1,52 & 1,46 & 0,79 & 3,52 & 8,17 & 4,39 & 4,31 & 4,75 \\
\hline Energia & 13,68 & 7,50 & 19,03 & 5,03 & 4,35 & $\mathbf{0 , 0 0}$ & 3,19 & 4,91 & 6,20 & 4,54 \\
\hline Manufaturas & 31,88 & 42,44 & 49,44 & 66,14 & 70,30 & 23,87 & 46,56 & 15,18 & 8,74 & 9,36 \\
\hline Manufaturas RRNN & 9,68 & 4,58 & 2,47 & 2,29 & 1,76 & 6,08 & 6,83 & 6,82 & 3,68 & 4,27 \\
\hline Manufaturas Não RRNN & 22,20 & 37,86 & 46,98 & 63,86 & 68,55 & 17,79 & 39,74 & 8,36 & 5,06 & 5,09 \\
\hline Outros & 0,04 & $\mathbf{0 , 0 1}$ & $\mathbf{0 , 0 0}$ & 0,01 & 0,01 & 1,79 & 0,26 & 0,08 & $\mathbf{0 , 0 2}$ & 0,03 \\
\hline
\end{tabular}

Fonte: Elaboração própria em base a TradeCan (2012). Segundo a CUCI Rev. 2 reagrupada por Mandeng (1993, p. 190). 
Tabela 3

Estrutura comercial do Brasil (exportações por destino)

\begin{tabular}{|c|c|c|c|c|c|c|c|c|c|c|}
\hline \multirow{2}{*}{ Participação setorial em \% } & \multicolumn{5}{|c|}{ MUNDO } & \multicolumn{5}{|c|}{ OCDE } \\
\hline & 1985 & 1990 & 2000 & 2007 & 2010 & 1985 & 1990 & 2000 & 2007 & 2010 \\
\hline Recursos Naturais & 51,48 & 42,64 & 39,84 & 43,98 & 51,60 & 55,49 & 47,92 & 44,03 & 45,48 & 52,43 \\
\hline Agricultura & 41,18 & 30,81 & 30,62 & 27,06 & 30,97 & 44,84 & 36,12 & 34,96 & 32,11 & 36,01 \\
\hline $\begin{array}{l}\text { Fibras Têxtil, Minerais e } \\
\text { Metais }\end{array}$ & 10,30 & 11,83 & 9,21 & 16,92 & 20,63 & 10,65 & 11,80 & 9,07 & 13,37 & 16,41 \\
\hline Energia & 3,62 & 2,10 & 2,29 & 6,94 & $\mathbf{9 , 0 8}$ & 3,93 & 2,42 & 2,68 & 8,32 & 12,09 \\
\hline Manufaturas & 44,22 & 54,56 & 56,43 & 47,87 & 37,76 & 39,92 & 49,07 & 51,20 & 44,65 & 33,07 \\
\hline Manufaturas RRNN & 6,39 & 9,75 & 9,42 & 8,99 & 6,09 & 6,72 & 10,94 & 11,71 & 11,99 & 7,64 \\
\hline Manufaturas Não RRNN & 37,84 & 44,82 & 47,01 & 38,88 & 31,67 & 33,20 & 38,13 & 39,49 & 32,66 & 25,43 \\
\hline Outros & 0,67 & $\mathbf{0 , 7 0}$ & 1,44 & 1,21 & 1,56 & $\mathbf{0 , 5 7}$ & $\mathbf{0 , 5 9}$ & 2,09 & $\mathbf{1 , 5 5}$ & 2,42 \\
\hline \multirow{2}{*}{ Participação setorial em \% } & \multicolumn{5}{|c|}{ Mercosul } & \multicolumn{5}{|c|}{ Ásia em Desenvolvimento } \\
\hline & 1985 & 1990 & 2000 & 2007 & 2010 & 1985 & 1990 & 2000 & 2007 & 2010 \\
\hline Recursos Naturais & 24,03 & 18,54 & 14,10 & 10,43 & $\mathbf{9 , 8 7}$ & 46,48 & 35,25 & 67,55 & 75,85 & 76,23 \\
\hline Agricultura & 14,50 & 8,73 & 10,29 & 5,02 & 5,40 & 32,90 & 17,73 & 45,11 & 35,41 & 36,87 \\
\hline $\begin{array}{l}\text { Fibras Têxtil, Minerais e } \\
\text { Metais }\end{array}$ & 9,53 & 9,81 & 3,81 & 5,41 & 4,47 & 13,58 & 17,52 & 22,44 & 40,43 & 39,37 \\
\hline Energia & 5,41 & 2,81 & 1,44 & $\mathbf{0 , 9 0}$ & $\mathbf{0 , 7 0}$ & 0,44 & $\mathbf{0 , 3 9}$ & $\mathbf{0 , 8 5}$ & 4,43 & 8,29 \\
\hline Manufaturas & 70,52 & 78,44 & 84,44 & 88,62 & 89,41 & 50,41 & 63,26 & 31,32 & 19,41 & 14,87 \\
\hline Manufaturas RRNN & 3,44 & 2,83 & 3,72 & 3,38 & 2,76 & 7,84 & 9,70 & 8,66 & 6,50 & 5,08 \\
\hline Manufaturas Não RRNN & 67,08 & 75,61 & 80,72 & 85,24 & 86,65 & 42,57 & 53,56 & 22,66 & 12,91 & 9,79 \\
\hline Outros & $\mathbf{0 , 0 2}$ & $\mathbf{0 , 0 8}$ & $\mathbf{0 , 0 2}$ & 0,04 & $\mathbf{0 , 0 2}$ & 2,67 & 0,96 & 0,22 & $\mathbf{0 , 3 0}$ & $\mathbf{0 , 5 9}$ \\
\hline
\end{tabular}

Fonte: Elaboração própria em base a TradeCan (2012). Segundo a CUCI Rev. 2 reagrupada por Mandeng (1993, p. 190) 
Virginia Laura Fernández, Marcelo Luiz Curado

\section{Anexo 2}

Tabelas com dados referentes às quotas de mercado nas importações mundiais. Por mercados (TradeCAN, 2012)

Tabela 1

Quota de mercado nas importações mundiais (em \%)

\begin{tabular}{l|c|c|c|cc}
\hline Bloque Importador & 1985 & 1990 & 2000 & 2007 & 64,19 \\
\hline OCDE & 83,20 & 80,70 & 73,66 & 68,46 & 1,63 \\
MERCOSUL & 1,32 & 1,04 & 1,54 & 1,89 \\
ÁSIA EM DESENVOLVIMENTO & 11,85 & 14,87 & 19,21 & 24,42 & 28,12 \\
\hline
\end{tabular}

Fonte: Elaboração própria com base em TradeCAN (2012). Cepal - Nações Unidas.

Gráfico 1

Evolução das importações mundiais (em milhares de dólares correntes)

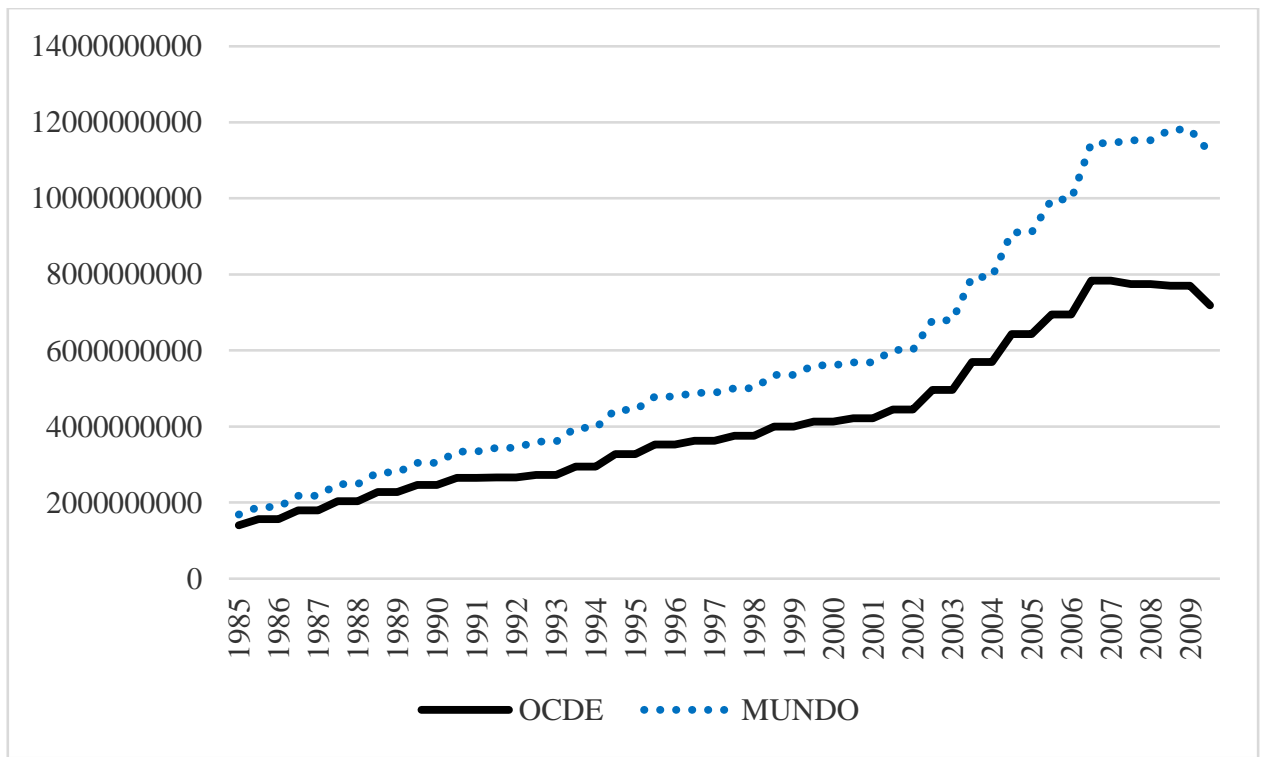

Fonte: Elaboração própria com base em TradeCAN (2012). Cepal - Nações Unidas. 
Gráfico 2

Evolução das importações mundiais 1985-2010 (em milhares de dólares correntes)

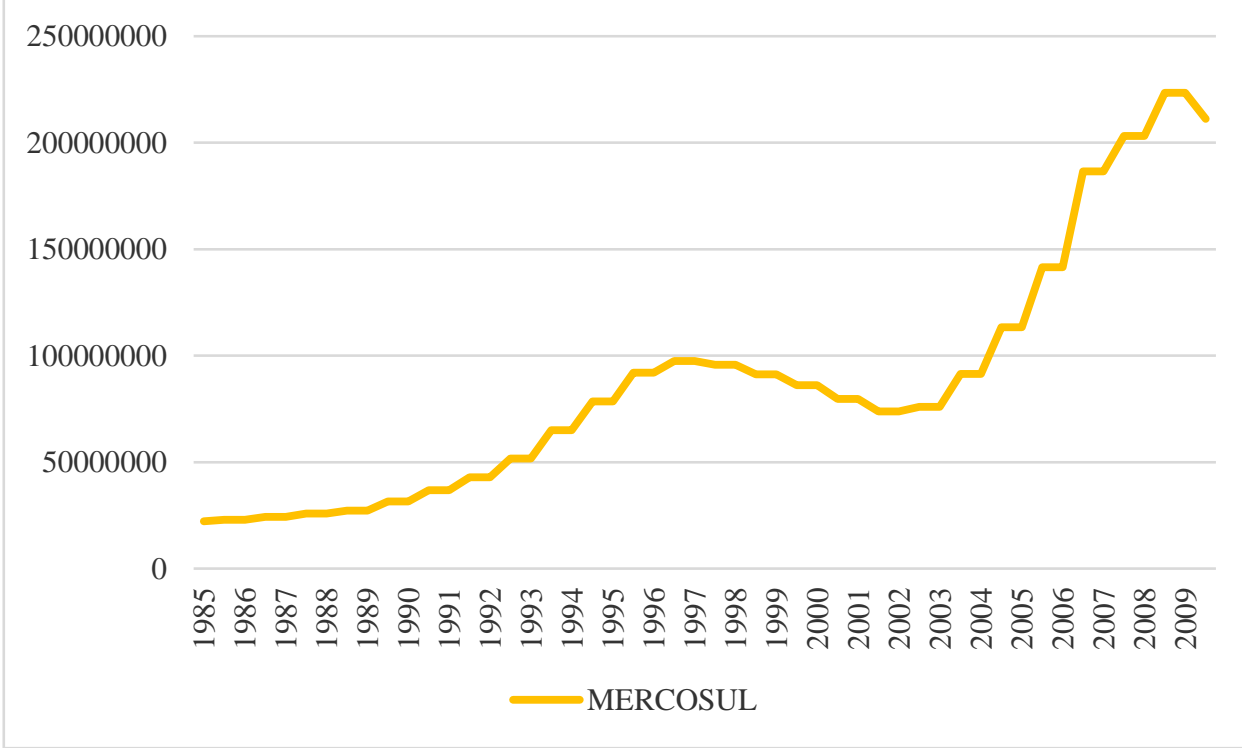

Fonte: Elaboração própria com base em TradeCAN (2012). Cepal - Nações Unidas.

Gráfico 3

Evolução das importações mundiais 1985-2010 (em milhares de dólares correntes)

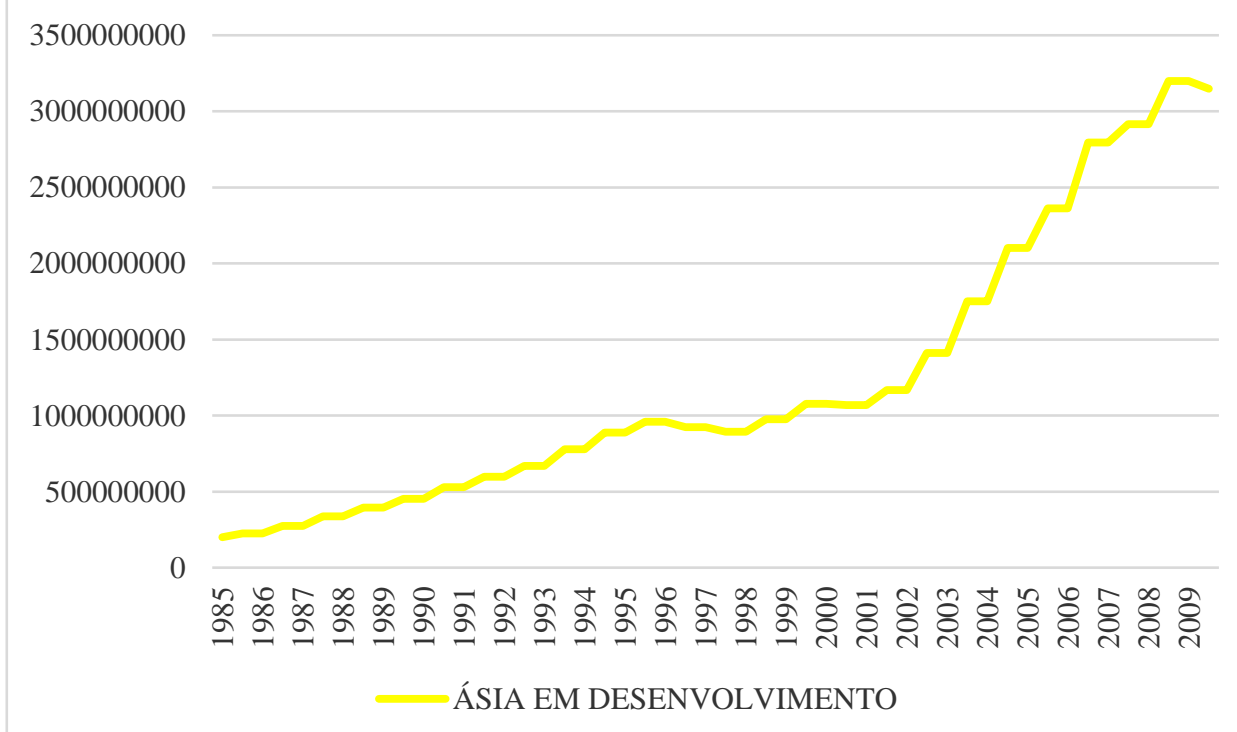

Fonte: Elaboração própria com base em TradeCAN (2012). Cepal - Nações Unidas. 